\title{
THE ANALYSIS OF THE BULLYING IN THE POEMS “I GOT FLOWERS” BY PAULETTE KELLY AND “INCIDENT” BY COUNTEE CULLEN
}

\author{
Fita Febrina \\ Student of STIBA-IEC Jakarta \\ Istiwarni Dyah, M.Pd. \\ Lecturer STIBA-IEC Jakarta \\ istiwarni@gmail.com
}

\begin{abstract}
The purpose of this thesis is to analyze about the kind of bullying that is reflected in the poems "I Got Flowers" and "Incident" and how the bullying occurs in each poem. The analysis uses qualitative and content analysis method. The data are taken from books. The results of the analysis are (1) There are five types of bullying; physical bullying, verbal bullying, emotional bullying, sexual bullying, cyber bullying which are common happen in society. (2) The speakers of the poems get bullying in the different ways. The speaker of poem "I Got Flowers", who is a woman, suffers verbal, physical, and emotional bullying from her husband but the speaker of poem "Incident", who is still a little child suffers verbal bullying due to discrimination of race. (3) The speakers of the poems also feel the effects after suffering the bullying. The speaker of "I Got Flowers" is beat to the death because of get the bullying action repeatedly but the speaker of "Incident" has trauma for eight months in Baltimore.
\end{abstract}

\section{Keywords: Bullying, Speaker, Suffer}

\section{A. INTRODUCTION}

\section{Background}

None of us can choose what the color of our skin, what tribe we are , and what gender we are because it is far from our mother's womb , God himself formed us. Everyone should understand that no one can underestimate and insult each other just because we were born in the difference. It means the physical shape, skin color, race, and gender are the absolute rights of God that 
cannot be denied by any human being. That difference is not something that serves to divide or barrier the peace in human life, but the diversity and differences that should be understood as a plurality of race which is a great gift of God.

However, the diversity cannot be accepted easily by the men. A man or group who feels better, stronger, or more civilized with other people or any other group is the forerunner to the emergence of a sense of discrimination. This discriminatory attitude will lead to racist attitudes, if they feel their race better and more perfect than the other racial groups. Understanding racist or racism itself is a practice to treat others differently, to provide an assessment as measured by the characteristics of racial, social, or certain mental concept. Racism is a problem because the concept is not just being a distinctive category, but rather it is intended to affirm the superiority of one party among other parties. Racism continues to grow from era to era. An act of rebellion over any differences is expressed as a "big umbrella" bullying.

Bullying has been identified as a problem that has become common in many countries around the world. It is very important to stop bullying as soon as possible. It can create a hell on earth for someone who becomes the victim, and can seriously threaten the convenience of human's life. Therefore, family, schools, and society have an important role where people develop most of their morality, their understanding of the sense of social responsibility to the community around them. Bullying is the act of destroying, and cyber-bullying is the latest expression. A number of young people have committed suicide as a result of cyber bullying. Suicide as a result of bullying is a shocking strike at school and the community in which it occurred. Bullying is not only physical damage but can also be psychological. It can be an act of isolation, humiliation, name-calling, spreading false rumors. It can involve money extortion. It can be sexual. It can be done by and for women. Although cuts and bruises are external signs of physical bullying, research shows that the internal pain of psychological intimidation can be as painful as the external pain. 


\section{The Objective}

The objectives within this analysis are (1) to identify the type of bullying reflected in "I Got Flowers" and "Incident" and (2) to comprehend the type of bullying represented in "I Got Flowers" and "Incident" poem.

\section{Theoretical Framework}

\subsection{Poetry}

\section{1) The Definition of Poetry}

Stanley Carr (2013) said poetry is "a verbal composition having the suggestive power to engage the feelings and imagination, typically through the highly structured patterning and movement of sound, rhythm, and meaning characterictic of verse". While Kathleen Kuiper (2011) explained poetry is "a genre of literature that evokes a concentrated imaginative awareness of experience or a specific emotional response through language chosen and arranged for its meaning, rhythm, and sounds". Oscar Mandell (1998) also stated poetry is "the branch of literature whose words and related signs are preponderantly delivered in premeditated limited quanta".

Based on the statements above, the writer concludes poetry is a branch of poetry to engage the feelings and imagination through language chosen and arranged for its meaning, rhythm, and sounds.

\section{2) The Elements of Poetry}

Every poem has essential elements that construct it to be a good poetry. According to Robert DiYanni (2000) that basic elements of poetry are needed, so that the reader can interpret and understand the poem well. Each element of the poetry can create a poem into a good one. The elements of poetry can also be considered as textual interpretation of poem.

Robert DiYanni also explained that "the elements of a poem include the speaker's voice inside the poem, diction, syntax, imagery, figures of speech, sound effects, rhythm and meter, and structure". 
While McDougal Littell (2001:292) recognized that "the basic elements of poetry are speaker, content, theme, shape and form, mood or tone, imagery and diction". From what the experts said above, the writer deduces there are seven elements of poetry that usually exist in poems. The basic elements of poetry are:

a. Speaker

The poem's speaker is the person who is addressing the reader. Sometimes, the speaker is the poet, who addresses the reader directly or another person. The poet reveals the identity of the speaker in various ways. Choice of words, focus of attention and attitudes will indicate the age, perspective and identity of the speaker.

According to John Timpane (2001), speaker is "Speaker, also known as persona, this is the imaginary person who "speaks" the words in a poem. Some poems feature speakers as full-fledged characters with names and histories. But for the sake of discussion, imagine all poems as having speakers."

\section{b. Theme}

The theme of the poem is the meaning of the poem - the main idea that the poet is trying to communicate. The theme may be stated directly or it may be implied.

Steve Bowkett (2009:49) stated "the theme of a poem is what it's about; the main idea that you are trying to express. It's bigger and deeper than a topic".

c. Form

Basically, the actual shape and form of poems can vary dramatically from poem to poem. In poetry, you will encounter two forms: structured and free verse. Structured poetry has predictable patterns of rhyme, rhythm, lines-length and stanza construction. Some examples are the sonnet and the haiku. In free verse, the poet experiments with the form of the poem. The rhythm, number of syllables per line, and stanza construction do not follow a pattern. 
K.V. Surendran (2002:95) defined form of poetry as "the manner in which a poem is composed as distinct from what the poem is about. Form also represents the final unity of a work, the effective combining of various parts into a whole".

d. Tone

The mood or tone of a poem is the feeling that the poet creates and that the reader senses through the poet's choice of words, rhythm, rhyme, style and structure. Poems may express many moods - humorous, sarcastic, joyous, angry or solemn.

Steve Bowkett said the tone of a poem is "its mood, and also the mood it aims to put you in as you read it".

e. Rhyme, Rhythm and Meter

Rhyme is the repetition of sounds. Judy Young (2013) defined rhyme as "two or more words that end in the same vowel and consonant sounds". Stephanie Borrusch (2015) identified that there are two types of rhyme that can be used:

1. Perfect rhymes which have vowels or consonants in common and are composed of synonyms that are true or exact. Examples of perfect rhymes are bug and rug, love and dove, and dear and fear.

2. Off rhymes which have vowels or consonants in common and are composed of synonyms that are imperfect, partial, or slant. Examples of off rhymes are word and lord, receive and give, and home and come".

While Christina Myers-Shaffer (200:80-81) recognized some of major rhyme forms and how they are used:

1. End rhyme is when the rhyming words fall at the ends of two or more lines of verse.

2. Echo verse employs a form of end rhyme used commonly in 1500 s and 1600 s in which the closing syllables of a line are repeated to form the next line.

3. Internal rhyme is two or more rhyming words within a line of verse.

4. Masculine rhyme is rhyme of single stressed syllable that generally is forceful: look, cook; sing, bring; sob, rob; sweet, treat. 
5. Feminine rhyme is rhyme of a stressed then unstressed syllable and, as a result, is softer than masculine rhyme: looking, cooking; feature, creature.

6. Compound rhyme is rhyme of both pairs of compound components: fish broth, dishcloth; cork-screw, pork stew.

7. Triple rhyme is rhyme of a stressed followed by two unstressed syllables: bacteria, diphtheria.

8. Perfect rhyme is an exact alignment of sounds, whereas imperfect rhyme is only a close alignment.

9. Eye rhyme looks like they should rhyme but do not such as horse, worse.

10. Identical rhyme consists of words that sounds the same but have different spellings and meanings: sees, seas; hare, hair; their, there; heart, hart.

11. Historical rhyme are words that once rhymed, but due to pronunciation shifts no longer rhyme: tea once rhymed with day.

12. Forced rhyme is "invented" by the poet. Along with eye rhyme and imperfect rhyme, forced rhyme is example of poetic license - when a poet departs from the usual use of rhyme, diction, syntax, and other such conventions.

Rhythm is a beat of a poem. According to Curtis D. Vick (2014:47), "rhythm is the pattern of stressed and unstressed syllables in a line of poetry". Curtis D. Vick also classified rhythm into six major types of formal rhythm in English Poetry:

1. lambic : two syllables foot with the stress on the second syllable

2. Trochaic : a stressed syllable followed by an unstressed syllable

3. Anapestic : three syllables with the stress on the last syllable

4. Dactylic : three syllables with the stress on the first syllable

5. Spondaic : two stressed syllables

6. Pyrrhic : two unstressed syllables 
Meter is the length of a line of poetry, based on what type of rhythm is used. Stephen Adams (1997:2) stated "meter refers to the abstract model for poetic measure"

Martin Stephen (2013:47) divided meter into eight terms. They are:

1. Monometer: one foot or units of metre per line

2. Dimeter : two feet or units of metre per line

3. Trimeter : three feet or units of metre per line

4. Tetrameter: four feet or units of metre per line

5. Pentameter: five feet or units of metre per line

6. Hexameter : six feet or units of metre per line

7. Heptameter: seven feet or units of metre per line

8. Octameter : eight feet or units of metre per line

f. Imagery

Imagery refers to the "pictures" which we perceive with our mind's eyes, ears, nose, tongue, skin, and through which we experience the "duplicate world" created by poetic language. Imagery evokes the meaning and truth of human experiences not in abstract terms, as in philosophy, but in more perceptible and tangible forms. This is a device by which the poet makes his meaning strong, clear and sure. The poet uses sound words and words of color and touch in addition to figures of speech. As well, concrete details that appeal to the reader's senses are used to build up images.

Daniel J. Pukstas (2006:56) stated "imagery might refer to the strong descriptive idea that the poem places in the reader's mind".

Nikki Moustaki (2001:57-60) classified the imagery as follows:

1. Visual Imagery describes how something looks, and enables the reader to visualize the objects or actions in a poem.

2. Auditory Imagery tries to capture a sound on paper, usually using a comparison to do so.

3. Tactile Imagery describes how something, even something intangible, feels, either to touch or to experience with the whole body.

4. Olfactory Imagery describes how something smells. 
5. Taste Imagery is another often - overlooked sense you can try to work into your poems.

6. Synesthesia combines two senses together, as in "a velvety voice", "sparkling silence", or being able to taste the color, as in "the sharp taste of yellow on my tongue"

g. Figure of speech

According to Perrine (1992:61), "Figure of speech may be defined as any way of saying something other than the ordinary way."

Figure of Speech is where a word or words are used to create an effect, often where they do not have their original or literal meaning. Figure of speech is, when the meaning of the words has a "deep" meaning, which is different from the "surface" meaning.

There are some types of figure of speech;

1. Alliteration is the repetition of initial consonant sounds in successive or closely associated words. Peter Piper picked a peck of pickled peppers

2. Assonance is the resemblance of similarity in sound between vowels followed by different consonants in two or more stressed syllables in a line of poetry. Then came the drone of a boat in the cove.

3. Hyperbole is a figure of speech in which conscious exaggeration is used for effect. I had a headache the size of a washtub.

4. Personification is a figure of speech in which animals, ideas, abstractions or inanimate objects are endowed with human qualities. Death reached down and carried the old man away.

5. Simile is a figure of speech in which a similarity between two objects or ideas is expressed using the words "like" or "as." She sings like a bird. Considering how much you hurt me, you might as well have put a dagger through my heart!

6. Metaphor is a figure of speech which imaginatively identifies one object with another and attributes to the first object one or more qualities of the second. Simply stated, a comparison that does not use "like" or "as." The pretty young girl is a vixen. John was a tiger in the battle, fighting with tooth and claw. 
7. Synecdoche is a figure of speech in which a part is used metaphorically to represent a whole, or a whole is used to represent a part. The factory had more than a hundred hands working three shifts. The Spanish Armada was 150 sail strong.

8. Metonymy is a figure of speech in which a closely associated object is used metaphorically to represent the thing, person, etc. with which it is associated. All of Magwitch's fortune was confiscated by the crown.

9. Litotes is a figure of speech in which something is expressed with a negation of the contrary. The soccer stadium was filled with no small number of exuberant fans.

10. Pathetic Fallacy is a type of personification in which inanimate nature is given human qualities. Every flower enjoys the air it breathes.

11. Oxymoron is a figure of speech in which opposites are paired for effect. Bittersweet. Jumbo shrimp. Deafening silence.

12. Onomatopoeia is a poetic sound device in which words are used that actually simulate the sounds they represent. Crash. Bang. Pop. Pow. Rattle.

13. Apostrophe is a type of personification in which an author addresses an inanimate or non-living object or idea as if that entity were alive and could converse with him. A good example is Keats' "Ode on a Grecian Urn" in which he directly addresses the urn. Another example is Shelley's "Ode to the West Wind" in which he speaks directly to the wind.

\section{The Enjambment of Poetry}

Some poets usually write their poems in the form of a story . A story that narrate personal experience or imagination. Writing poetry that resembles a story called the enjambment.

Bernhard Lang (2013:137) stated that enjambment may be defined as the continuation of syntax and sense across line junctures without a major pause. Roland Greene (2012:435) defined enjambment as the continuation of syntactic unit from one line to the next without a major juncture or pause 
While Martin J. Duffel (2008:9) said that the severance of a syntactic unit by a line boundary is termed enjambment. Geoffrey N. Leech (2014:125) explained that enjambment is really a matter of degree - of degree of grammatical cohesion between the end of one line and the start of the next belong.

\subsection{Bullying}

\section{a. The Definition of Bullying}

According to Montgomery (1994:3) Bullying is a behavior that can only be easily recognized when individuals experience it. Montgomery said "So far, it is difficult to define bullying since it relates to wide range behavior that may constitute bullying, and the characteristics of bullying behavior." However, the most common definition in use was adopted by Olweus (1991:413). Olweus defined "bullying, but more carefully and restrictive, as "repeated, negative actions over time, including hitting, kicking, threatening, locking inside a room, saying nasty and unpleasant things, and teasing." Ken Rigby (2008:22) suggests that bullying is the systematic abuse of power in interpersonal relationship. In other words, bullying is when a person is picked on over and over again by an individual or group with more power, either in terms of physical strength or social standing. Ken Rigby argues that the abuse of power is not restricted only to certain managerial or "authority" positions, but that most individuals have "the opportunity to exercise power to control over someone." Thus, Olweus said that there are apparently imbalances in physical and psychological strength between bully and the victim. Regarding the recognition of bullying, Olweus and Solberg, have suggested some typical characteristics to recognize bullying behavior. They said that "we generally speak of bullying when one or more persons repeatedly and over a period of time say or do painful and unpleasant things to someone who has problems defending himself or herself". To address the terms "painful" and "unpleasant" experience, Olweus and Solberg refer them as direct bullying and indirect bullying. They argue that "the pain and unpleasantness may be due to direct bullying involving hitting, kicking, insults, offensive and sneering comments or threat while indirect 
bullying, which is just as painful, is the experience of being socially isolated and excluded from group membership."

Sally Kuykendall (2012:1) also stated that bullying is an abusive, malicious, and intentionally hurtful action, In bullying, the bully is not trying to solve a problem but trying to hurt the victim.

Based on the opinions of the above, it can be concluded that bullying is as follows:

1) Bullying is a behavior that is illegal, negative and aggressive in the social environment. Bullying has differences with the aggressive behavior seen from the difference in length of time, where bullying will be sustained, while aggressive behavior only one time opportunity with a short time. The effect is twofold effect of short-term and long-term.

2) Bullying gives effects until adulthood and this behavior is a manifestation of his or her parents' lifestyle in one's childhood.

3) This behavior often occurs as a result of isolation is done by peers. Real consequence is emerging depression in a person who becomes a victim of bullying.

Based on these data, it can be concluded generally by the writer that bullying is an aggressive behavior, illegal, such as hitting and taunting negative in a social environment and occur because of social isolation.

\section{b. The Causes of Bullying}

Bullying can happen to everyone at all ages and everywhere whether at school, home, or even in a workplace.

Sensei Serge Sognonvi and Carmen Sognonvi (2010) through their website wrote the top 5 reasons why the bullies bully:

1) Bullies have a strong need to be in control and exert their dominance over others

2) Bullies are rewarded for their bullying behaviors

3) Bullies are lack of emphaty and may even get pleasure out of other's people pain

4) Bullies are lack of ability to self regulate emotions.

5) Bullies are heavily influenced by their family background 
Meanwhile, McCarthy, et.al argued that generally there are two causes of why people do the bullying behavior especially at work:

1). Personal Causes of Bullying: The Prepetrator

The most frequent reasons gave for their being bullied was "they wanted to push me out of this company". The second reason most commonly given is located on the responsibility for the bullying with a particular person. Other reasons given for the bullying included a weak superior, competition for tasks, status or advancement, or competition for the supervisor's favour.

2). Organizational Causes of Bullying

Career pathways may either not exist, as in many parts of the social and health services, or be less influenced by achievement and depend more on seniority, time in the organization and relationships. These factors may well increase micro-politics at work, which, coupled with the poor conflict resolution, increase the level of bullying reported among these occupations and industry sectors.

A second related reason may be that the work performance in this occupations and sectors may be more difficult to appraise. These difficulties could also be a source of potential conflict. A third reason, for the higher reports of bullying by office workers and managers than by factory workers is related to the level of job skills and tenure.

N.C. Stella (2007:8-11) concludes that bullying to the children can be caused by many things, for example: changes in the family, changing views of discipline, the emotional attitude of parents, the use of physical punishment and violent emotional outburst, being a victim of another bully, competition at school, and poor childhood.

Batsche and Moore (1992, p.8-9) suggest that the following environmental factors may contribute to the development of bullying behavior:

1. Too little supervision of children and adolescents. Children need to get the message that bullying behavior is not okay. 
2. A "payoff". When parents or other adults give in to an obnoxious or aggressive child, the child learns to use bullying to get what he or she wants.

3. Aggressive behavior in the home. Some children are more likely than others to imitate aggressive behavior. Watching adults bully each other gives children the tools they need to become bullies themselves.

4. Harsh physical punishment. Bullies often attack smaller, weaker children to model what happens to them in their homes. The worst possible punishment for bullies is physical.

5. Abusive peers. Children may be bullied by their "friends" or may encourage to bully to be part of the group.

6. Constant negative feedback. Bullies feel that the world around them is more negative than positive as a result. they use negative behavior to feel important and get attention.

7. Expecting hostility. In many ways, the bully's philosophy is "the best defense is offense." They attack before they are attacked, and assume hostility where none may exist.

There isn't a clear reason why a child may become a bully, but SuEllen Fried and Paula Fried (1996) felt that environmental factors can lead to the development of bullying behaviors. The pattern of behavior can begin as early as age two; the older the child becomes, the more difficult change will be. SuEllen Fried and Paula Fried also felt child bullies are at greater risk for problems in the future. For example, by age thirty, 25 percent of the adults who had been identified as bullies as children had a criminal record.

\section{c. The Types of Bullying}

Bullying takes many forms. It can appear in many ways. McGrath (2007, p.6) classified three types of bullying are:

a. Physical Bullying: Harm to another's person or property

b. Emotional Bullying: Harm to another's self-concept 
c. Relational Bullying: Harm to another through damage (or the threat of damage) to relationships or to feelings of acceptance, friendship, or group inclusion.

According to Anna. C. Baldry (2004:343), "bullying can be categorized into two forms, direct bullying and indirect bullying." Both of these forms of bullying are executed by both boys and girls. Direct bullying is easier to detect as it involves physical contact, therefore making it action-orientated. This type of bullying occurs in the form of physical assault, such as hitting, pulling of hair, punching, poking, kicking, pushing, smacking, taking possessions such as lunch or money, damaging possessions and forcing someone to do things against his/her will

Another form of direct bullying is known as verbal bullying. In these cases, the bully uses words to hurt or humiliate his/her victim. This type of bullying may occur in the form of taunting, teasing, name-calling, threats of harm, hate speech, passing degrading remarks about the victim (this may be with reference to the victims physical appearance) or verbally abusing a victim (Physical and verbal bullying predominately occurs in the playground, before and after school and during school excursions Indirect bullying can be divided into two types: relational bullying and emotional bullying. These are less easy to detect, making it more difficult for teachers to respond. Relational and emotional bullying makes the victim feel alienated and alone. Relational bullying is purposeful and is aimed at destroying a victim's relationship with others and spoiling their reputation. The bully will not direct his aggression at the victim but instead influences others with whom the victim comes into contact. Relational bullying can involve social exclusion from a group, spreading nasty rumors about a person or gossiping

Emotional bullying occurs in the form of humiliation, black mailing and terrorizing. Studies conducted by Anna C. Baldry (1998:155), revealed that girls are more prone than boys to engage in relational bullying. In general, boys rely more upon overt forms of bullying - (hitting, kicking and threatening, for example). Although bullying usually occurs out of teachers' sight, subtler bullying can occur within the classroom. These behaviours include social 
exclusion, such as name-calling, gossiping, teasing or refusing to work with someone in the class.

There is also sexual bullying which appears to be distinct from sexual harassment, a form of behaviour that certainly overlaps with what is generally understood as bullying behaviour. There are some examples we may infer the sexual bullying;

a. Such exchanges are commonplace between boys and girls in the secondary school.

b. One or both of the children in the exchange are being offensive.

c. Language with sexual connotations is being used .

Advance in technology also creates bullying behavior in a different form, through space and time, which we are familiar with cyber crime or cyber bullying. With easy access to technology, the problem of adolescent cyber bullying has increased. Though bullying still occurs in the traditional form of face-to-face contact, cyber bullying is becoming more common as youth have more access to the Internet, cameras, and text messaging via cell phones.

According to Hinduja and Patchin (2012:32) "cyberbullying is willful and repeated harm inflicted through the use of computers, cell phones, and other electronic devices."

From the explanations above, the writer concludes that there are five types of bullying as follows:
a. Physical Bullying
b. Verbal Bullying
c. Emotional Bullying
d. Sexual Bullying
e. Cyber Bullying

All types of bullying above are common happen in society.

\section{Methodology}

This research was a descriptive research aimed at providing description pertaining to the kind of data gathered and analyzed. According to Klenke (2008, 
p.9) notes most methods under the qualitative umbrella imply the emphasis on processes and meanings that are rigorously examined but not measured in terms of quantity, amount, or frequency. This research was carried out by formulating the problem, collecting the data, classifying, and explaining the result. This research was for analyzing the bullying conflict that was reflected in "Incident" and "I Got Flowers" poems. Based on the problem analyzed, this research used descriptive qualitative research method.

\section{B. RESULT AND DISCUSSION}

\section{Bullying In The Poems}

Bullying can occur in any context in which human beings interact with each other. This includes school, church, family, workplace, neighborhood, and home. The poem describes how the bullying occurs at home where it is done by the husband to his wife.

\section{We had our first argument last night,} and he said a lot of cruel things that really hurt me.

This statement indicates that the husband hurts her by saying a lot of cruel things. It shows a form of verbal bullying. So, the writer concludes that the bullying at home always starts by arguing each other between husband and wife.

I know he was sorry and didn't mean the things he said because he sent me flowers today.

The wife forgives his husband because he gives her flowers. This part tells the woman's feeling how she is easy to hurt but also easy to forgive. This woman's weaknesses makes bullying continues to occur even it can get worse. The next part explains more that the bullying comes greater than just words. 
Last night he threw me into a wall and started to choke me. It seemed like a nightmare. I couldn't believe it was real.

I woke up this morning sore and bruised all over.

In this part, the words "threw" and "choke" indicate that the woman got physical bullying from her husband. "I woke up this morning sore and bruised all over" marks that she gets not only a physical bullying but also physical injuries. The word "nightmare" can be interpreted as something bad that haunts the speaker. It means the writer finds the woman gets haunted.

"I know he must be sorry because he sent me flowers today". After getting the worse bullying, the woman still wants to forgive her husband. This makes the writer wonder whether forgiving him is the right decision or actually makes their behavior much worse. And what is the reason behind his wife's forgiveness?

Last night he beat me up again, and it was much worse than all the other times.

The writer finds that in the next part, the bullying is getting much worse to her than what she gets before. The word "beat" still indicates that the woman gets the physical bullying again.

If I leave him, what will I do? How will I take care of my kids?

What about money? I'm afraid of him and scared to leave.

The following part describes the reason why the woman still survives while forgiving again and again. It is because she is worried of herself and her kids. She is afraid of him. She is afraid about money. The writer concludes that most of women who feel the bullying at home have the same reason. They are afraid to get rid of themselves from the bullying behavior. 
"But I know he must be sorry. Because he sent me flowers today." The flowers re-emerged as a symbol of apology from her husband against his wife

I got flowers today. Today was a very special day.

It was the day of my funeral.

Last night he finally killed me. He beat me to death.

Finally the woman is dead. She is dead in regretting why she lets her husband kill her. She wishes she can have courage to fight She wishes if she has the courage to fight bullying, maybe she will not die. She will live better.

From the explanations above, the writer concludes that the bullying behavior can be started by arguing each other. Forgiving cannot stop the bullying. It just makes much worse than before. This poem showed how bullying can be done by everyone even by someone who has close relationship with us and how physical bullying is actively carried out also can impact the mental of the victim.

Bullying behaviors come in a variety of forms, Bullying is not simply physical in nature. It can be indirect in nature and there are not always bruises or cuts left behind. Most victims of bullying do not have physical wounds that are visible to the human eye. The pain of bullying does not always heal like a bruise. The pain of bullying continues to haunt victims of bullying long after.

The poem Incident implied there is a bullying action happened to the black person in Baltimore.

\section{I saw a Baltimorean.}

Keep looking straight at me.

The statement indicates that the Baltimorean feels that the presence of the speaker in Baltimore is something strange. Keep looking straight at has meaning that the speaker has become the center of attention of the Baltimorean's eyes and only the person who has something unique or strange will be the center of attention. 
The next stanza of the poem will tell the reason why the speaker becomes The Baltimorean's focus.

Now I was eight and very small,

And he was no whit bigger,

In this sentence, the speaker describes himself that he/she is eight years old with the small body, and "he" that refers to the Baltimorean has same appearance with the speaker. So, the writer can conclude that they, the speaker and the Baltimorean boy, are still children.

And so I smiled, but he poked out

His tongue, and called me, "Nigger."

It explains how innocent the speaker is. He/she smiles at the Baltimorean boy even though he keeps looking straight at the speaker. It seems that the speaker wants to be a friend with him. However, his innocence is responded by the insulting words "Nigger" while poking his tongue out. If the writer is back at the point when the history of Nigger told, it shows that there is racism issue between The White (Baltimorean) and The Black (the speaker) through the insulting words and insulting action. Any acts of violence or insulting carried out both verbally and physically is bullying behavior.

This poem is so ironic because remembering that the perpetrator is an eight years old boy. The bullying due to racism seems a heritage from generation to generation so that every child also assumes that every person who is hated by his father and mother is also his enemy. The racism led to bullying. The different background of race causes why the Baltimorean boy bullies the black skin speaker. However the analysis above comes from the Baltimorean boy's point of view. It will be different if the writer analyzes through the speaker's point of view.

As the speaker, who gets bullying and several discrimination acts from the white people in the young age, is not easy. In his/her innocence, maybe he/she just wants to be a friend or just wants to know each other. However, the rejection comes too fast and suddenly. So, it is possible to shock him. Moreover, the speaker 
doesn't know the why reason. From the way the speaker's get bullying from the Baltimorean, the writer concludes that the speaker suffers verbal bullying.

\section{I saw the whole of Baltimore}

From May until December;

Of all the things that happened there

That's all that I remember.

The stanza tells about the effects of the bullying behavior. The speaker feels the nightmare for eight months. It can be concluded that the verbal bullying needs more times to heal especially it happens to a child. They are usually easy to get trauma in their life.

From the explanations above, the writer concludes that the speaker suffers verbal bullying because the Baltimorean boy calls him "Nigger". "Nigger" is the negative connotation that is commonly used by the white people to insult and underestimate the black people. The incident that happens to the eight years old boy hurts him emotionally and become trauma for eight months.

\section{CONCLUSIONS}

The writer puts high expectation that this thesis can help the readers especially the students of literature, to be easier in analyzing the English poetry. The writer realizes that to read poem is not easy so the writer hopes the students will be more interested in reading or analyzing poems.

Poem is an art work that is expressed in the beautiful and meaningful words based on the poet's feeling or experience and conveys the message to the readers. Kinds of poem are ballad, blank verse, free verse, haiku, and sonnet. Poem also has elements such as theme, tone, imagery, figure of speech, rhyme and rhythm.

Theme is the main idea in the poem. Determining the theme of a poem can help the readers or the students to get the meaning of poem more clearly. Background of a poem is the reason why the writer chooses the theme. 
In this thesis, the writer analyses the poems and takes the similarities and differences by using qualitative research. For collecting the data, the writer searches from the internet and books. After that, the writer makes summary by comparing the similarities and differences. The writer uses the technique of analyzing data by reading the poems, interpreting the poems, and finding the similarities and differences of the poems.

As objectives of the thesis, the writer explains that this thesis is written to analyze the bullying action in Incident poem and I Got Flowers poem. The main idea of poems is the bullying action to the African boy and bullying action to the woman that is done by her husband. 


\section{BIBLIOGRAPHY}

Adams, Stephen. Poetic Designs: An Introduction to Meters, Verse Forms, and Figures of Speech. Broadview Press. 1997

Baldry, Anna.C.. 2004. Aggressive Behavior. Wiley Liss.

Baldry, Anna C.. Bullying among Italian middle school students: combining methods to understand aggressive behaviours and victimisation. School Psychology International. 1998

Batsche, George and Moore, Benjamin. 1992. Helping Children Grow Up In the 90's. The Association.

Borrusch., Stephanie. In flight with Sixth Grade Language Arts - Student Edition. Complete Curriculum. 2015

Bowkett, Steve. Countdown to Poetry Writing: Step by Step Approach to Writing Techniques for 7-12 Years. Routledge. 2009

Carr,Stant. Poetry Made Simple. n.d. 2013

Diyanni, Robert. Literature: Reading Fiction, Poetry, and Drama. USA: McGraw-Hill Higher Education. 2000

Greene, Roland and Stephen Cushman. The Princeton Encyclopedia of Poetry and Poetics. Princeton University Press. 2012

Hinduja, Sameer and Patchin, Justin W. School Climate 2.0: Preventing Cyberbullying and Sexting One Classroom at a Time. Corwin Press. 2012

J. Duffel, Martin. A New History of English Metre. MHRA. 2008

Kuiper, Kathleen. Poetry and Drama:Literary Terms and Concepts. New York: The Britannica. 2011

Kuykendall, Sally. Bullying. ABC-CLIO. 2012

Lang, Bernhard. International Review of Biblical Studies vol.48. Brill. 2003 
Laurence, Perrine and Thomas R. ARP. Sound and Sense; An Introduction to Poetry, $8^{\text {th }}$ ed. Southern Methodist University. 1992

Littell, McDougal. English. USA: Pennsylvania State University Press. 2001

Mandell, Oscar. Fundamentals of The Art of Poetry. England: Sheffield Academy Press. 1998

McCarthy, Paul et al. Bullying From Backyard To Boardroom. The Federation Press. 2001

McGrath, Mary Jo. School Bullying: Tools For Avoiding Harm and Liability. Corwin Press. 2007

Montgomery, R. P. G. Coping strategies of children who are victimized by bullying. University of Houston, USA. 1994

Myers - Shaffer , Christina. How to Prepare for SAT II.: Literature. Barron's Educational Series. 2000

N. Leech, Geoffrey. A Linguistic Guide to English Poetry. Routledge. 2014

Nikki Moustaki. The Complete Idiot's Guide To Writing Poetry. Penguin. 2001

Olweus, Dan. Bully/Victim problems among schoolchildren: Basic facts and effects of a school based intervention program. In Debra, J. Pepler and Kenneth $\mathrm{H}$. Rubin. (eds.) The development and treatment of Childhood aggression.Erlbaum. 1991

Olweus, Dan and Solberg, Mona E. Bullying Among Children And Young People. Information and guidance for parents. Pedagogisk forum. 1998

Pukstas., Daniel J. The Path To Poetry. iUniverse. 2006

Rigby, Ken. Children and Bullying. How parents and educators can reduce bullying at school. Blackwell Publishing. 2008

Stella, N.C. 2007. How parents can help stop bullying. Upfront Publishing Ltd.

Stephen, Martin. English Literature: A Student Guide. Routledge. 2013 
SuEllen Fried and Paula Fried. Bullies \& Victims: Helping Your Children through the Schoolyard Battlefield. M.Evans Company, Inc. 1996

Surendran, K.V. Indian English Poetry: New Perspectives. Sarup \& Sons. 2002

Timpane, John. Poetry For Dummies. John Wiley \& Sons. 2011

Vick, Curtis D. The Poetry Book. Xlibris Corporation. 2014

Young , Judy. $R$ is for Rhyme: A Poetry Alphabet. Sleeping Bear Press, 2013 